\title{
Spatial Distribution of Neighborhood-level Housing Prices and Its Association With All-cause Mortality in Seoul, Korea (2013-2018): a Spatial Panel Data Analysis
}

Ikhan Kim ( $\square$ ikhan.kim@kosin.ac.kr)

Department of Medical Humanities and Social Medicine, Kosin University College of Medicine

\section{Research}

Keywords: Housing, Health Status Disparities, Residence Characteristics, Socioeconomic Factors, Spatial Analysis, Elasticity, Republic of Korea, Seoul

Posted Date: December 31st, 2020

DOl: https://doi.org/10.21203/rs.3.rs-136737/v1

License: (c) (i) This work is licensed under a Creative Commons Attribution 4.0 International License. Read Full License

Version of Record: A version of this preprint was published at SSM - Population Health on November 1st, 2021. See the published version at https://doi.org/10.1016/j.ssmph.2021.100963. 
Spatial distribution of neighborhood-level housing prices and its association with all-cause mortality in Seoul, Korea (2013-2018): A spatial panel data analysis

Ikhan Kim

Department of Medical Humanities and Social Medicine, Kosin University College of Medicine, Busan, Korea

Corresponding author: Ikhan Kim, Department of Medical Humanities and Social Medicine, Kosin University College of Medicine, 262 Gamcheon-ro, Seo-gu, Busan 49267, Korea. Email address: ikhan.kim@kosin.ac.kr Tel: +82-51-990-6704. Fax: +82-51-990-6704. 


\section{Abstract}

Background: Housing prices are known to be a relevant indicator of the socioeconomic position of the neighborhood. In a society where the market system mainly drives housing prices, residents' spatial patterning is formulated according to their socioeconomic position.

Methods: Dividing the 2013-2018 entire study period into three periods, we explored the geographical distribution of housing prices and all-cause mortality and their association in Seoul, where the country's capital city. The government authorities' data and 2015 census data were used for the study. We mapped the geographical distribution of housing prices and allcause mortality and investigated the changes in distribution. We conducted a pooled OLS and spatial panel regression analysis to estimate housing prices elasticity of all-cause mortality. We also explored the possible mediating role of housing prices on the educational composition's effect on all-cause mortality.

Results: We found the common trends of increasing spatial patterning of housing prices and all-cause mortality. The magnitude of spatial patterning was far greater in housing prices than all-cause mortality. In a pooled OLS regression analysis, we found that a $1 \%$ increase in housing price was associated with a $0.11 \%$ reduction in all-cause mortality after controlling the explanatory variables. Attenuation in the regression coefficient's magnitude was found after adding the neighborhood's educational composition in the model. As a result of spatial panel analysis, we found a direction and scale similar to the housing price elasticity of all-cause mortality in the final pooled OLS model. 
Conclusions: The results suggested that geographical health inequality in Korea's urban space mainly stemmed from the affinity of high socioeconomic position and the more developed spaces.

\section{Keywords}

Housing; Health Status Disparities; Residence Characteristics; Socioeconomic Factors; Spatial Analysis; Elasticity; Republic of Korea; Seoul. 


\section{Background}

In a society where housing is highly commercialized, the residence is mostly determined by people's ability to mobilize their socioeconomic resources (1). Housing is a unique asset that generates revenue in the form of vested rent and provides housing services $(2,3)$. Housing systems, such as housing policies and the real estate market, and the social and physical environment jointly influence housing values $(4,5)$. Thus, housing value reflects both neighborhood and individual-level conditions, including neighborhood social status, wealth, and housing conditions (4).

In many cities, economic inequality in urban areas is increasing (6-8). (9) asserted that problems that arise in cities turn into a product of capital accumulation and class conflict when the assumption is converted from "where you live affects your life" to the belief that "your life affects where you live." (10) also argued that, to deal with urban health inequality, the question "where is power and who works?" should be asked. (11) stated that urban health inequalities stemmed from "systematically unequal distribution in power, prestige, and resources associated with relative position in the social hierarchy." Taking the housing price into account would make it possible to examine cities' health problems through the lens of health inequality.

Korea is one of the countries that has experienced rapid economic growth since the $1960 \mathrm{~s}$ (12). The capital Seoul has rapidly become urbanized. London developed from one million to eight million residents in approximately 130 years, while Bangkok took 45 years, and Seoul only 25 years (6). The state's role was to promote industrialization by mobilizing political and economic means (13). Under the development ideology of the industrialization period, the authoritarian government united with economic power, while civil society and laborers were 
excluded from discourse formation and development profit distribution (14). Survival through diligent household saving was prioritized over public welfare policies. The housing provision policy was implemented to alleviate the distribution conflict and grow the middle class, which has been friendly to the ruling powers. The fruits of economic growth were realized individually through housing market gains using savings as leverage (15).

Korea's housing system is highly market-driven, and housing accounts for a substantial portion of capital. As of 2019 , real estate accounts for $75.5 \%$ of total wealth, which is much higher than other countries, of which housing accounted for 55.0\% (16). High housing values are clustered in Seoul's downtown area, especially in the southeastern part of the city (Gangnam area) and its surroundings (17). It contrasts with the United States and some European countries, where central urban districts are economically deprived and have been subject to gentrification in general (18). These areas attracted the above middle-class residents due to their dense upmarket physical and social environments, including excellent educational opportunities, convenient transportation, abundant consumption and cultural facilities, and stable housing asset values $(17,19,20)$.

The geographical distribution and changes in the neighborhood and individual socioeconomic position (SEP) can interactively cause intra-urban variation in health levels (11, 21-25). Understanding Seoul's processes is necessary to understand the health inequality of the country's urban spaces because Korea's other regions have mimicked what has happened in the capital (14).

This study assessed the ecological association between neighborhood-level all-cause mortality and housing value. First, we explored the geographical distribution of housing prices and all-cause mortality in Seoul. Second, we estimated the housing price elasticity of all-cause 
mortality using a pooled ordinary least squares (OLS) model. The educational composition was added to the model to explore the possible mediating role of housing prices in the pathway of educational composition on all-cause mortality. Third, a spatial fixed-effects regression analysis was performed, and the magnitudes of elasticity were compared with those from the pooled OLS model.

\section{Methods}

Data

The six years of the entire study period (2013-2018) were divided into three discrete periods (2013-2014, 2015-2016, 2017-2018). The standard housing rental contract period in Korea is two years, so we assumed that population movement would mainly occur in two years. It is also known that if the relative risk is between 1.5 and 2.0, the empirical Bayes is not powerful when the denominator does not exceed 70 (26). When the two-year data were combined, expected deaths were less than 70 in $3.2 \%$ of all neighborhoods. We used several types of administrative data. The data on the number of populations and deaths by neighborhood were from the Ministry of Interior and Safety. The neighborhood-level annual population and death counts have been collected and published online (https://www.mois.go.kr/). We calculated the mid-term population by period/gender/neighborhood using the number of populations at the end of December every year. We used the housing price data of the Ministry of Land, Infrastructure, and Transport, which contains the entire real housing transaction price in the country. In Korea, all house sales contract information must, by law, be reported to the authority 
within one month of the contract's date (27). The authority discloses the collected data through its website, and the disclosed information includes address, sale price, and contract date (https://rt.molit.go.kr/). The Seoul Metropolitan Government's information disclosure system (Seoul Open Data Plaza, http://data.seoul.go.kr) was used to acquire the data on each neighborhood's characteristics.

Unit of analysis

The smallest administrative unit was set as the unit of analysis, the smallest unit to obtain the data used herein. It can also maximize comparability with previous Korean studies investigating the health gap at the small-area level (28-30). As of $31 \mathrm{Dec}, 2018,424$ units were adjusted to 423 in consideration of administrative change. A neighborhood was assumed as the smallest administrative unit.

Outcome variable

All-cause mortality was used as the outcome variable. All-cause mortality for each neighborhood was estimated using the sex-age-adjusted standardized mortality ratio (SMR).

Variable of interest

The variable of interest was the median value of housing prices in neighborhoods. We assumed the median housing price as an appropriate proxy for the local area's $\operatorname{SEP}(31,32)$. During the entire study period, there were a total of 928,405 housing transactions in Seoul. 
Geographic coordinates were derived using the contract address. In 19,348 (2.1\%) cases where the exact address was unclear, the coordinates were designated by the smallest administrative unit's centroid.

Explanatory variables

Previous studies have suggested that physical and social environments, population composition, health, and social services as urban living conditions that influence health outcomes $(11,23,33-36)$. The physical environment includes transportation systems, housing, population density, pollution, and the social environment includes economic development, quality of education, social norms, and social capital $(23,25,33,34)$. We used four neighborhood-level factors (poverty rate, population density, business workers density, the number of nearby subway stations), and four district-level factors (the number of physicians per 1,000 population, particulate matter (PM) 10 annual concentration, park area per person, and local tax amount).

We estimated the poverty rate using the proportion of Basic Livelihood Security Program (BLSP) benefits recipients. The Korean government pays BLSP benefits to households whose income amount is below a certain standard, considering income, poverty, and dependent family size. As of 2018, the proportion of BLSP recipients is about $3.4 \%$ of the national population. In previous Korean studies, the proportion of BLSP beneficiaries was also used as a proxy for poverty $(37,38)$ because it is difficult to obtain the poverty level of neighborhoods directly. The population density and that of business workers were estimated using each neighborhood area $\left(\mathrm{km}^{2}\right)$ as the denominator. The nearby subway station was set as the number of subway stations within a 10-minute walk. PM10 is the average annual district-level PM10 
concentration in $\mu \mathrm{g} / \mathrm{m}^{3}$. Local tax amounts had a strong relationship with the district's SEP, and it was also related to the introduction of health policy introduction or health resource access $(39,40)$. Educational composition data for each neighborhood were obtained from the 2015 Census data. Educational composition and poverty rates were adjusted for gender and age using an indirect standardization method in the same way as the outcome variable (41).

\section{Statistical analysis}

An indirect standardization method was applied to calculate the all-cause mortality as a sexage-adjusted SMR. The standard population was the total population of Seoul from 2015 to 2016. Each neighborhood's SMR was smoothed using the empirical Bayes method. If the main goal is smoothing the relative risk, the empirical Bayes method is known to yield results similar to those of the full Bayes method (26). We mapped the distribution of neighborhood-level housing prices and all-cause mortality in Seoul during the study period. Global and local Moran's I value (42) were used to examine the degree of spatial clustering of the two variables.

The educational composition could only be obtained from the 2015 census data. We therefore performed a pooled OLS analysis using education level variables. We regressed unsmoothed SMR on housing prices and other explanatory variables. All variables were log-transformed to form a log-log model. The equation used in the pooled OLS analysis was as follows:

$$
\ln \left(\mu_{i}\right)=\sum_{j} \ln \left(X_{j i}\right) \beta_{j}+u_{i}
$$

where $\mu_{i}$ is the unsmoothed SMR of neighborhood $i, X_{j i}$ is the $j^{\text {th }}$ explanatory variable of neighborhood $i, \beta_{j}$ is the regression coefficient of the $j^{\text {th }}$ explanatory variable, and $u_{i}$ is an 
error term of neighborhood $i$.

A simple and robust Lagrange multiplier (LM) test using non-spatial regression models was performed to examine the existence of spatial autocorrelation (43). We also estimated the Global and Local Moran's I values of the residuals of the non-spatial Poisson model. Previous studies have attempted to solve the spatial autocorrelation problem by including additional variables in the regression equation $(44,45)$. We organized data into time-series cross-sectional data and analyzed it using a space and time fixed-effects spatial Durbin error model (SDEM). SDEM is a combination of the spatially lagged-X (SLX) model that assumes the effect of the explanatory variables of the neighboring areas on the outcome variable of the area (spillover effect), and the spatial error model (SEM), which assumes the interaction between the unobserved variables in neighboring areas and the area (46-48). We believe that the local spillover effect was more appropriate as the outcome variable of the current study was a social aggregate $(49,50)$. We constructed the row-standardized queen contiguity spatial weights of order $1 . \mathrm{R}^{2}$ and pseudo- $\mathrm{R}^{2}$ values were used to determine the fitness of the models. The equation used in the spatial panel analysis was as follows:

$$
\begin{gathered}
\ln \left(\mu_{i t}\right)=\sum_{j} \ln \left(X_{j i t}\right) \beta_{j}+\sum_{j} W \times \ln \left(X_{j i t}\right) \theta_{j}+\alpha_{i}+\gamma_{t}+u_{i t} \\
u_{i t}=\lambda W u_{i t}+\varepsilon_{i t}
\end{gathered}
$$

where $\mu_{i t}$ is the unsmoothed SMR of neighborhood $i$ at time $t, X_{j i t}$ is the $j^{\text {th }}$ explanatory variable of neighborhood $i$ at time $t, W$ is the contiguity weight matrix, $\theta_{j}$ is the regression coefficient of the $j^{\text {th }}$ spatially lagged explanatory variable. $\alpha_{i}$ is the fixed effects of neighborhood $i$, and $\gamma_{t}$ is the fixed effects of time. $u_{i t}$ is an error term of neighborhood $i$ at time $t$, composed of spatial and non-spatial factors $\left(\varepsilon_{i t}\right) . \lambda$ is the coefficient value for the 
spatial error term.

This study used the "splm" package in R 3.6.3 (https://www.r-project.org), and QGIS 3.12.1 (https://www.qgis.org), GeoDa 1.14.0 (https://geodacenter.github.io) for the analysis.

\section{Results}

The characteristics of neighborhoods by period are reported in Table 1. The median population in 2013-2014 was 24,108 , the minimum value was $1,495.5$, and the maximum value was $673,374.5$. The interquartile range (IQR) was $12,879.8$. The median number of deaths in 2013-2014 was 185, and the minimum and maximum were 8 and 492, respectively. The median population tended to decrease, but the median number of deaths increased. In 20132014, the median housing price was 366.6 million KRW (IQR 171.5 million KRW, 1 million KRW is approximately 900 US dollars as of Nov. 2020). The minimum was 135.5 million KRW, and the maximum was 1,480 million KRW. The median housing price increased by $13.3 \%$ in 2015-2016 compared to 2013-2014 and $21.4 \%$ in 2016-2017 compared to 2014-2015. The IQR also rose significantly from 171.5 in $2013-2014$ to 301.0 in 2017-2018. This difference seems mainly due to the rise in prices in neighborhoods where housing prices were already high (Supplementary Figure 1). Compared to each decile's value in 2013-2014, the rate of increase was greater in the high housing price decile (A). In the comparison between the boundary value for each decile and the median value (50 percentile), the higher decile boundary value increased more (B).

The mapped distribution and histogram of smoothed SMR in Seoul during the study period 
is depicted in Figure 1. In 2013, the mean value of the smoothed SMR was 1.07, and the standard deviation (SD) was 0.16 , all of which decreased with time. The maximum and minimum SMR value was 2.86 in 2013-2014, 2.30 in 2015-2016, and 2.57 in 2017-2018. During the entire study period, the southeastern part of Seoul and its surroundings showed a relatively lower SMR than the other parts of Seoul. The northern region and some western parts showed clustered higher SMR than other areas.

The ratio of each decile value of SMR in 2013-2014 to the value for each decile in 20152016 and 2017-2018 is presented in Supplementary Fig 2. All ratios decreased with time, especially in the high mortality deciles (A). The ratio of the SMR for each decile to the median value was also shown by period (B). The ratio between the 10-40 percentiles and the median value did not change significantly with time. However, the ratio decreased substantially in the 60-90 percentiles and median.

The geographical median housing price distribution for each period is mapped in Figure 2. Housing prices were high in the southeastern part and its surroundings, and low housing prices were observed in the northern and some western parts of Seoul. The degree of clustering measured by Global Moran's I increased (0.515 in 2013-2014 and 0.541 in 2017-2018). The marginal and joint distribution of log-transformed housing prices and SMR for each period are shown in Supplementary Figure 3. SMR and housing prices showed a negative correlation. The Pearson correlation coefficients (r) were the smallest at -0.456 in 2013-2014 and the largest at -0.538 in $2015-2016$.

Each neighborhood's educational composition in 2015 is mapped and the Global and Local Moran's I at each educational level is estimated in Supplementary Figure 4. We found a similar spatial pattern between tertiary education proportion and housing price. We also found mirror 
images of primary and tertiary education. Global Moran's I values were 0.557 in primary education, 0.614 in secondary education, and 0.572 in tertiary education. Pearson correlation coefficients among neighborhood-level educational composition and housing price are shown in Supplementary Table 1. Primary and secondary education variables showed a significant negative association with the median housing price variable (-0.690 in primary education, 0.794 in secondary education). In contrast, the tertiary education variable showed a positive association $(\mathrm{r}=0.741)$.

The results of Global and Local Moran's I values for the z-transformed residuals of SMR estimated using the Poisson regression model are presented in Supplementary Figure 5. Compared to 2013-2014, Global Moran's I value increased in 2015-2016 and 2017-2018 (0.170 in 2013-2014, 0.269 in 2015-2016, and 0.258 in 2017-2018). In the LM test, spatial autocorrelations were significant in all-cause mortality (Supplementary Table 2). However, significant spatial autocorrelation disappeared after the neighborhood's educational composition was added to the model (Model 4) in 2015-2016.

The results of the pooled OLS regression analysis are reported in Table 2. In Model 1, the $1 \%$ increase in housing price was associated with a $0.20 \%$ decrease in all-cause mortality $(95 \%$ confidence interval (CI) -0.22 to -0.18 ). In Models 2 and 3, the regression coefficient attenuated after adding the other neighborhood and district-level explanatory variables, but was still significantly associated with the mortality decrease. When the educational composition variable was added to the model (Model 4), the magnitude of regression coefficient of the housing price variable was $-0.05(95 \%$ CI -0.08 to --0.03$)$.

The results of the spatial panel analysis are reported in Table 3. In Model 5, the regression coefficient for housing prices was -0.05 (95\% CI -0.07 to -0.02$)$, in which the magnitude was 
similar to the results in Model 4. The magnitude of the regression coefficients in poverty and population density was relatively large and significant. Among the spatially lagged variables, the housing price and subway station variables showed a statistically significant association. In Model 6, we added district-level explanatory variables and found that magnitude and direction of the association were not significantly changed.

\section{Discussion}

Calculating the smoothed SMR for each neighborhood in Seoul revealed that the average and the variance decreased over time, but the spatial patterning increased. Housing prices were also spatially more clustered. Using the pooled OLS model, the all-cause mortality decreased by approximately $0.11 \%$ as the housing price increased by $1 \%$. After adding the educational composition to the model, the magnitude of the housing price effect was attenuated (a $1 \%$ increase in housing prices was related to a $0.05 \%$ mortality decrease). When including educational composition and housing prices simultaneously in the model, the spatial autocorrelation was not statistically significant. When we used the fixed-effects SDEM, a 1\% increase in housing prices was related to a $0.05 \%$ decrease in all-cause mortality.

The use of a neighborhood-level SEP has several advantages. It can be used for all ages and can be similarly applied to gender (51). It is also relatively more stable than income or job indicators, mainly reflecting current circumstances $(51,52)$. It is also possible to include those excluded when using traditional occupational-based indicators (53). A single variable, housing prices closely related to the level of wealth, was used as a proxy for the neighborhood-level 
SEP. Wealth is regarded as a source of economic security and power and can function as a buffer against economic shocks (51). A single variable measure is relatively easy to calculate, and it can be estimated every year to ensure continuity. Previous studies conducted in Korea mainly used the deprivation index as a regional SEP indicator $(28,30,54)$. However, if a single index that can explain the specific association is used, the process of determining the urban health level would be better understood.

The average and variance of all-cause mortality were found to decrease simultaneously. In particular, the forces to lower mortality in areas with high mortality have led to a reduction in dispersion. Two recent studies presented mixed results in changes in the variance of all-cause mortality. (55) observed time-series changes in German state-level mortality during a 25-year study period and found that mortality levels converged despite large economic gaps between regions. On the other hand, a study conducted in Scotland revealed that lifespan variation increased during 1981-2011 (53). The first reason for the decrease in mortality variation could be the weaker association between housing prices and mortality as the former increase. (56) suggested the Preston curve, which demonstrated a log-linear relationship between regional gross domestic product per capita and life expectancy. As of 2017, the average life expectancy in Seoul was 82.57 years, 80.18 years for males, and 85.01 years for females. In the situation where the declining force of all-cause mortality was saturated, it is possible that the mortality in areas where the SEP was relatively high and the mortality was low stagnated, whereas the mortality decreased when the SEP was low. Another possible cause is residential mobility. The housing market plays a key role in determining where urban residents live $(57,58)$. In particular, when housing prices rise rapidly, residents with low SEP are less likely to be able to afford to purchase or rent houses, and they can be excluded from those areas involuntarily (57). Seoul 
has a much higher housing price and living cost than other regions. In addition, the rate of increase in housing prices has been steeper in Seoul than in other regions. In 2010, real estate assets were a significant indicator of movement outside Seoul (59). Therefore, we speculate that the movement of low SEP outside Seoul as housing price rises could induce a decrease in mortality variation. The application of social and public health policies or health systems can be another potential cause (60).

According to the results of the current study, the spatial patterning of housing prices and allcause mortality increased, especially housing prices. (61) argued that socioeconomic resource distribution was one of the most important causes of spatial health inequality. Neighborhood differences are not naturally formed but are shaped through various social and economic processes $(62,63)$. Since the late 1960s, urbanization in Korea has progressed along with industrialization led by the central government. Rapid urbanization leads to an increase in the overall economic level, but it also creates socioeconomic inequalities within the city (11). The development of the southeastern part of Seoul began in the 1960s, and the middle class rushed into the area. The changes in the proportion of those who received tertiary education among the district's population on a 10-year basis are shown in Supplementary Figure 6. Between 1975 and 1985 , the proportion of tertiary education in the southeastern part of Seoul, indicated in red, increased sharply. This rate solidified between 1985 and 1995. The rich educational and cultural environments that were constructed to promote the internal migration of the middle class at the time of development brought educational capital inheritance to the next generation and a stable housing asset value (17). As affluence became visible, the southeastern part of Seoul became the object of desire and was imitated across the country (14). Some previous studies argued that the composition and contextual effect division is a false dualism, and they 
mutually reinforce each other $(10,22,64)$. Thus, spatial clustering potentially solidifies over time and affects residents' health by itself $(34,65)$. Future studies should explore the effect of spatial patterning on health level.

Access to health-protecting resources, such as health care, better nutrition, and hygiene, seems to be determined depending on education level $(66,67)$. There are also differences in health-related knowledge, health behaviors, and attitudes to potential health threats (68). Fundamental cause theory explains that differences in health outcomes arise due to relative differences in access to resources according to the social hierarchy $(69,70)$. (71) found that residences of Seoul's power elites were clustered in the city's southeastern area. Considering the evident health inequality according to the SEP in Korea $(72,73)$, Seoul's geographical health inequalities seem to appear through the high SEP population's affinity for a better environment sorted by housing price.

In addition to housing prices, variables related to place development or composition changes, such as poverty rate or population density, significantly influenced the mortality rate. A previous study revealed that a higher population density lowered the region's health levels (74). However, in Seoul, the supply of large residential complexes, such as high-rise apartments, has been closely related to areal development. This raises the importance of developing the area and the composition change in determining the spatial patterning of mortality levels.

The current study has some limitations. First, additional variables may affect mortality. For example, the region's informal reciprocity level affects health, but this variable could not be included in the study. We utilized a fixed-effect spatial panel analysis to minimize the omitted variable bias. Second, this study adopted an ecological design using time-series cross-sectional data. The disadvantage of an ecological study is that it is impossible to partition the influence 
of factors at various levels. (75) also emphasized the importance of individual-level factors in small-area studies. However, the purpose of this study was not to sharply separate the effect of contextual and compositional factors. Rather, it was to clarify neighborhood-level mortality and SEP's geographical distribution and their association under the implicit assumption that compositional and contextual factors reinforce each other. It should be noted that the results should be explained at the group level. Third, internal migration is considered to be one of the major factors affecting mortality variation. Due to data limitations, the change in population composition according to neighborhood SEP changes could not be captured. Fourth, a neighborhood was used as the smallest administrative unit. Setting an administrative unit as such may differ from the residents' perception or actual living circumstances. However, using an administrative unit can aid policy decisions or resource allocation (65). Furthermore, the effect of various definitions of the neighborhood was not substantively significant on health inequality estimates (76). Fifth, actual transaction data were used to estimate the median housing price of the neighborhood. It has the advantage of being able to better measure the actual value of the house rather than the appraisal data. However, since it only includes the housing in which the transaction was made, it can over- or under-represent a specific type of housing.

\section{Conclusions}

This study explored the geographical distribution of all-cause mortality and housing prices and estimated the elasticity of housing prices to all-cause mortality. There were differences in change patterns in these, but an increase in spatial patterning was common. The association between housing prices and all-cause mortality was significant. When the educational 
composition and housing prices were added to the model simultaneously, spatial autocorrelation was not significant, and the effect of housing prices attenuated, indicating its potential mediating role in the educational composition's effect on all-cause mortality. This study is meaningful in explaining some of the health gap mechanisms that occur in the current urban space of Seoul. Based on this research, the mechanism should be further clarified, and the basis for policy intervention should be prepared. In future studies, spatial patterning effects on health level accounting for population movement should be investigated.

\section{List of abbreviations}

IQR: Interquartile range; OLS: Ordinary least squares; SDEM: Spatial Durbin error model; SEM: Spatial error model; SEP: Socioeconomic position; SLX: Spatially lagged-X; SMR: Standardized mortality ratio 


\section{Declarations}

\section{Ethics approval and consent to participate}

This study was approved by the Institutional Review Board (IRB) of Kosin University (IRB No. 2020-0065). Informed consent was waived for this study because secondary data were used.

\section{Consent for publication}

Not applicable

\section{Availability of data and materials}

The data that support the findings of this study are available from the Statistics Korea (https://kosis.kr) and the Seoul Metropolitan Government (https://data.seoul.go.kr).

\section{Competing interests}

The authors declare that they have no competing interests.

\section{Funding}

This research did not receive any specific grant from funding agencies in the public, commercial, or not-for-profit sectors. 


\section{Acknowledgments}

This work was presented at a symposium at the Korea Inequality Research Network and a conference at the Korean Society for Preventive Medicine. The author thanks the participant's helpful and constructive comments. 


\section{REFERENCES}

1. Bernard $P$, Charafeddine $R$, Frohlich $K L$, Daniel $M$, Kestens $Y$, Potvin L. Health inequalities and place: a theoretical conception of neighbourhood. Soc Sci Med. 2007;65(9):1839-52.

2. Atkinson AB. Inequality - What can be done? (Translated in Korean). Seoul: Geulhangari; 2015.

3. Piketty T. Capital in the Twenty-First Century (Translated in Korean). Seoul: Geulhangari; 2014.

4. Mehdipanah R, Schulz AJ, Israel BA, Mentz G, Eisenberg A, Stokes C, et al. Neighborhood Context, Homeownership and Home Value: An Ecological Analysis of Implications for Health. Int J Environ Res Public Health. 2017;14(10).

5. Mari-Dell'Olmo M, Novoa AM, Camprubi L, Peralta A, Vasquez-Vera H, Bosch J, et al. Housing Policies and Health Inequalities. Int J Health Serv. 2017;47(2):207-32.

6. World Health Organization \& United Nations. Human Settlements Programme. Hidden cities: unmasking and overcoming health inequities in urban settings. World Health Organization; 2010.

7. OECD. Divided Cities: Understanding Intra-urban Inequalities. Paris: OECD Publishing; 2018.

8. Massey DS. The Age of Extremes: Concentrated Affluence and Poverty in the Twenty-First Century. Demography. 1996;33(4):395-412.

9. Slater T. Your Life Chances Affect Where You Live: A Critique of the 'Cottage Industry' of Neighbourhood Effects Research. International Journal of Urban and Regional Research. 2013;37(2):367-87.

10. Bambra C, Smith KE, Pearce J. Scaling up: The politics of health and place. Soc Sci Med. 2019;232:36-42.

11. Friel $S$, Akerman $M$, Hancock $T$, Kumaresan $J$, Marmot $M$, Melin $T$, et al. Addressing the social and environmental determinants of urban health equity: evidence for action and a research agenda. J Urban Health. 2011;88(5):860-74.

12. Deaton A. The Great Escape. Seoul, Korea: The Korea Economic Daily \& Buiseness Publications; 2015.

13. Kim D. A History of Welfare Capitalism in South Korea (In Korean). Seoul: Seoul National University Press; 2018.

14. Hwang J. Building a developmental urban matrix: a Busan city case study. Journal of The Korean Association of Regional Geographers. 2016;22(2):331-52.

15. Park H. Apartment Game (In Korean). Seoul: Humanist; 2013.

16. Statistics Korea. Survey of Household Finances and Living Conditions Daejeon: Statistics Korea; 2019 [Available from: http://kostat.go.kr/portal/korea/kor_nw/1/4/4/index.board?bmode=read\&bSeq=\&aSeq=379367\&p 
ageNo=1\&rowNum $=10 \&$ navCount $=10 \&$ currPg $=\&$ searchlnfo $=\&$ sTarget $=$ title \&sTxt $=$.

17. Park B, Jang J. Gangnam-ization and Korean Urban Ideology. J Korean Association Regional Geographers. 2016;22(2):287-306.

18. Galea S, Ettman CK, Vlahov D. Urban Health. New York, United States of America: Oxford University Press; 2019.

19. Choi E. The Differentiation of Reproductions of Educational Capitals and the Formation of the Gated City. J Korean Geographical Society. 2004;39(3):374-90.

20. Choi E. The Formation of Rigid Cycle of the Rich in Gangnam - According to the Change of Condo Prices (1989-2004). J Korean Geographical Society. 2006;9(1):33-45.

21. Cummins $S$, Curtis $S$, Diez-Roux AV, Macintyre $S$. Understanding and representing 'place' in health research: a relational approach. Soc Sci Med. 2007;65(9):1825-38.

22. Meijer M, Rohl J, Bloomfield K, Grittner U. Do neighborhoods affect individual mortality? A systematic review and meta-analysis of multilevel studies. Soc Sci Med. 2012;74(8):1204-12.

23. Galea S, Freudenberg N, Vlahov D. Cities and population health. Soc Sci Med. 2005;60(5):1017-33.

24. Diez Roux AV, Green Franklin $T$, Alazraqui $M$, Spinelli $H$. Intraurban variations in adult mortality in a large Latin American city. J Urban Health. 2007;84(3):319-33.

25. Northridge ME, Sclar ED, Biswas P. Sorting out the connections between the built environment and health: a conceptual framework for navigating pathways and planning healthy cities. J Urban Health. 2003;80(4):556-68.

26. Ugarte MD, Goicoa T, Militino AF. Empirical Bayes and Fully Bayes procedures to detect high-risk areas in disease mapping. Computational Statistics and Data Analysis. 2009;53:2938-49.

27. Real Estate Transaction Report Act, 17219 (2020).

28. Yoon TH, Noh M, Han J, Jung-Choi K, Khang YH. Deprivation and suicide mortality across 424 neighborhoods in Seoul, South Korea: a Bayesian spatial analysis. Int J Public Health. 2015;60(8):969-76.

29. Kim JH, Yoon TH. [Comparisons of health inequalities in small areas with using the standardized mortality ratios in Korea]. J Prev Med Public Health. 2008;41(5):300-6.

30. Choi MH, Cheong KS, Cho BM, Hwang IK, Kim CH, Kim MH, et al. Deprivation and mortality at the town level in Busan, Korea: an ecological study. J Prev Med Public Health. 2011;44(6):242-8.

31. Oakes MJ, Andrade KE. The measurement of socioeconomic status. Methods in Social Epidemiology. Oakes MJ, Kaufman JS, editors. CA, USA: Jossey-bass 2017.

32. U.S. Census Bureau ACSA. A10036. Median House Value for All Owner-Occupied Housing Units [1] - Social Explorer Tables: ACS 2014 (5-Year Estimates) (SE) - ACS 2014 (5-Year Estimates): Social Explorer; [Available from: https://www.socialexplorer.com/data/ACS2014_5yr/metadata/?ds=SE\&table=A10036.

33. Borrell C, Pons-Vigues $M$, Morrison J, Diez E. Factors and processes influencing health 
inequalities in urban areas. Journal of epidemiology and community health. 2013;67(5):389-91.

34. Diez Roux AV, Mair C. Neighborhoods and health. Ann N Y Acad Sci. 2010;1186:125-45.

35. Macintyre S, Ellaway A, Cummins S. Place effects on health: how can we conceptualise, operationalise and measure them? Soc Sci Med. 2002;55(1):125-39.

36. Vlahov D, Freudenberg N, Proietti F, Ompad D, Quinn A, Nandi V, et al. Urban as a Determinant of Health. J Urban Health. 2007;84:16-26.

37. Park Y. A Study on the Residential Segregation of the Poor and foreign Population: A Case Study of Seoul Metropolitan City. Seoul Studies. 2011;12(4):103-22.

38. Lee YA. A Study on the Distribution and Formation Process of Deprived Areas in Korea. J Korean Urban Geographical Soc. 2015;18(1):45-56.

39. Do YK, Park KD. Local governments' dependence on tobacco tax revenue: a deterrent to tobacco control in the Republic of Korea. Bull World Health Organ. 2009;87:692-9.

40. Lee SY, Do YK, Shin SD, Park YJ, Ro YS, Lee EJ, et al. Community socioeconomic status and public access defibrillators: A multilevel analysis. Resuscitation. 2017;120:1-7.

41. Milyo J, Mellor JM. On the importance of age-adjustment methods in ecological studies of social determinants of mortality. Health Serv Res. 2003;38(6 Pt 2):1781-90.

42. Anseline L. Local Indicators of Spatial Association - LISA. Geographical Analysis. 1995;27:93115.

43. Anseline L, Bera AK, Florax R, Yoon MJ. Simple diagnostic tests for spatial dependence. Regional Science and Urban Economics 1996;26(1):77-104.

44. Ross M, Homer E. Galton's Problem in Cross-National Research. World Politics. 1976;29(1):128.

45. Franzese R, Hays J. Contagion, Common Exposure, and Selection: Empirical Modeling of the Theories and Substance of Interdependence in Political Science. Concepts \& Methods: Newsletter of the International Political Science Association. 2008;4(2):3-9.

46. Elhorst JP. Chapter 6. Spatial Models. Advanced Methods for Modeling Markets. Leeflang PSH, Wieringa JE, Bijmolt THA, Pauwels KH, editors. Cham, Switzerland: Springer International; 2017. 47. LeSage JP. What Regional Scientists Need to Know about Spatial Econometrics. The Review of Regional Studies. 2014;44:13-32.

48. Vega SH, Elhorst JP. THE SLX MODEL. J Regional Science. 2015;55(3):339-63.

49. Franzese R, Hay J. Accounting for Space in Comparative Political Analysis. CP: Newsletter of the Organized Section on Comparative Politics of American Political Science Association Spring 2016. 2016:83-7.

50. Cook S, Hays J, Franzese R. Chapter 39. Model Specification \& Spatial Econometrics. Curini L, Franzese R, editors: SAGE; 2020.

51. Krieger N, Williams DR, Moss NE. Measuring social class in US public health research: concepts, methodologies, and guidelines. Annu Rev Public Health. 1997;18:341-78. 
52. Pickett KE, Pearl M. Multilevel analyses of neighbourhood socioeconomic context and health outcomes: a critical review. Journal of epidemiology and community health. 2001;55(2):11122.

53. Seaman $R$, Riffe $T$, Leyland AH, Popham $F$, van Raalte $A$. The increasing lifespan variation gradient by area-level deprivation: A decomposition analysis of Scotland 1981-2011. Soc Sci Med. 2019;230:147-57.

54. Shin $H$, Lee $S$, Chu JM. [Development of composite deprivation index for Korea: the correlation with standardized mortality ratio]. J Prev Med Public Health. 2009;42(6):392-402 (Korean). 55. van Raalte AA, Klusener $S$, Oksuzyan A, Grigoriev P. Declining regional disparities in mortality in the context of persisting large inequalities in economic conditions: the case of Germany. Int J Epidemiol. 2020;49(2):486-96.

56. Preston $\mathrm{S}$. The changing relation between mortality and level of economic development. Popul Stud. 1975;29:231-48.

57. Modai-Snir T., van Ham M. Neighbourhood change and spatial polarization: The roles of increasing inequality and divergent urban development. Cities. 2018;82:108-18.

58. Smith SJ, Easterlow D. The Strange Geography of Health Inequalities. Trans Inst Br Geog. 2005;30(2):173-90.

59. Ryu K, Joung H, Suh S. A study on the Residential Mobility Characteristic by the Level of Income and Assets. J Korea Planning Association. 2013;48(5):145-63.

60. Asaria P, Fortunato L, Fecht D, Tzoulaki I, Abellan JJ, Hambly P, et al. Trends and inequalities in cardiovascular disease mortality across 7932 English electoral wards, 1982-2006: Bayesian spatial analysis. Int J Epidemiol. 2012;41(6):1737-49; discussion 50-2.

61. Kramer MR. Chapter 14. Race, Place, and Space: Ecosocial Theory and Spatiotemporal Patterns of Pregnancy Outcomes. Howell FMea, editor. Switzerland: Springer International Publishing; 2016.

62. Diez Roux A. Invited Commentary: Places, People, and Health. American journal of epidemiology. 2002;155(6):516-9.

63. Link BG. Epidemiological sociology and the social shaping of population health. J Health Soc Behav. 2008;49(4):367-84.

64. Frohlich KL, Corin E, Potvin L. A theoretical proposal for the relationship between context and disease. Sociology of Health \& IIIness. 2001;23(6):776-97.

65. Krieger N, Kim R, Feldman J, Waterman PD. Using the Index of Concentration at the Extremes at multiple geographical levels to monitor health inequities in an era of growing spatial social polarization: Massachusetts, USA (2010-14). Int J Epidemiol. 2018;47(3):788-819.

66. Jerrett $M$, Eyles J, Cole D. Socioeconomic and environmental covariates of premature mortality in Ontario. Soc Sci Med. 1998;47(1):33-49.

67. Rydland HT, Solheim EF, Eikemo TA. Educational inequalities in high- vs. low-preventable 
health conditions: Exploring the fundamental cause theory. Soc Sci Med. 2020:113145.

68. Osler M, Prescott E. Educational level as a contextual and proximate determinant of all cause mortality in Danish adults. Journal of epidemiology and community health. 2003;57(4):266-9. 69. Link BG, Phelan J. Social conditions as fundamental causes of disease. J Health Soc Behav. 1995;Spec No:80-94.

70. Phelan JC, Link BG, Tehranifar P. Social conditions as fundamental causes of health inequalities: theory, evidence, and policy implications. J Health Soc Behav. 2010;51 Suppl:S28-40.

71. Kim CS, Yun SC, Kim HR, Khang YH. [A multilevel study on the relationship between the residential distribution of high class (power elites) and smoking in Seoul]. J Prev Med Public Health. 2006;39(1):30-8 (Korean).

72. Khang YH, Lynch JW, Kaplan GA. Health inequalities in Korea: age- and sex-specific educational differences in the 10 leading causes of death. Int J Epidemiol. 2004;33(2):299-308.

73. Jung-Choi $\mathrm{K}$, Khang $\mathrm{YH}$, Cho HJ. Socioeconomic differentials in cause-specific mortality among 1.4 million South Korean public servants and their dependents. Journal of epidemiology and community health. 2011;65(7):632-8.

74. Vlahov D, Galea S. Urbanization, urbanicity, and health. J Urban Health. 2002;79(4 Suppl 1):S1-S12.

75. Merlo J, Viciana-Fernandez FJ, Ramiro-Farinas D, Research Group of Longitudinal Database of Andalusian P. Bringing the individual back to small-area variation studies: a multilevel analysis of all-cause mortality in Andalusia, Spain. Soc Sci Med. 2012;75(8):1477-87.

76. Stafford $\mathrm{M}$, Duke-Williams $\mathrm{O}$, Shelton N. Small area inequalities in health: are we underestimating them? Soc Sci Med. 2008;67(6):891-9. 
Table 1. Characteristics of study subjects by period.

\begin{tabular}{|c|c|c|c|c|c|c|}
\hline & $\begin{array}{l}2013-2014 \\
(\mathrm{~N}=423)\end{array}$ & & $\begin{array}{l}2015-2016 \\
(\mathrm{~N}=423)\end{array}$ & & $\begin{array}{l}2017-2018 \\
(\mathrm{~N}=423)\end{array}$ & \\
\hline Variables & $\begin{array}{l}\text { Median } \\
\text { (Min, Max) }\end{array}$ & IQR & $\begin{array}{l}\text { Median } \\
\text { (Min, Max) }\end{array}$ & IQR & $\begin{array}{l}\text { Median } \\
\text { (Min, Max) }\end{array}$ & IQR \\
\hline \multicolumn{7}{|l|}{ Neighborhood-level } \\
\hline Population, $\mathrm{n}$ & $\begin{array}{l}24108 \\
(1495.5 \\
673374.5)\end{array}$ & 12879.8 & $\begin{array}{l}23706.0 \\
(943.0 \\
666213.0)\end{array}$ & 12312.5 & $\begin{array}{l}23613.0 \\
(1010.0 \\
672340.0)\end{array}$ & 12863.2 \\
\hline Death, $\mathrm{n}$ & $\begin{array}{l}185 \\
(8,492)\end{array}$ & 96 & $\begin{array}{l}192 \\
(10,497)\end{array}$ & 113 & $\begin{array}{l}194 \\
(12,573)\end{array}$ & 118 \\
\hline $\begin{array}{l}\text { Housing price, } \\
1 \text { million KRW }\end{array}$ & $\begin{array}{l}366.6 \\
(135.5 \\
1480.0)\end{array}$ & 171.5 & $\begin{array}{l}415.5 \\
(140.0 \\
1530.0)\end{array}$ & 236.0 & $\begin{array}{l}504.6 \\
(135.0 \\
2565.0)\end{array}$ & 301.0 \\
\hline Poverty & $\begin{array}{l}0.71 \\
(0.01,6.19)\end{array}$ & 0.51 & $\begin{array}{l}0.93 \\
(0.01,6.42)\end{array}$ & 0.70 & $\begin{array}{l}0.99 \\
(0.01,6.04)\end{array}$ & 0.73 \\
\hline $\begin{array}{l}\text { Population density, } \\
\text { inhabitants } / \mathrm{km}^{2}\end{array}$ & $\begin{array}{l}24782.8 \\
(742.7 \\
65563.0)\end{array}$ & 17927.3 & $\begin{array}{l}24329.1 \\
(703.7 \\
63438.6)\end{array}$ & 17426.2 & $\begin{array}{l}24071.6 \\
(753.7 \\
60116.7)\end{array}$ & 17783.3 \\
\hline $\begin{array}{l}\text { Business workers, } \\
\text { employees } / \mathrm{km}^{2}\end{array}$ & $\begin{array}{l}6169.85 \\
(318.8 \\
105533.3)\end{array}$ & 7048.5 & $\begin{array}{l}6813.3 \\
(341.0 \\
120243.9)\end{array}$ & 7641.2 & $\begin{array}{l}6859.7 \\
(391.6 \\
110341.9)\end{array}$ & 7188.8 \\
\hline Subway stations, $\mathrm{n}$ & $\begin{array}{l}3 \\
(1,17)\end{array}$ & 4 & $\begin{array}{l}3 \\
(1,17)\end{array}$ & 4 & $\begin{array}{l}4 \\
(1,17)\end{array}$ & 4 \\
\hline Primary education & & & $\begin{array}{l}0.98 \\
(0.13,1.99)\end{array}$ & 0.42 & & \\
\hline Secondary education & & & $\begin{array}{l}0.97 \\
(0.13,1.52)\end{array}$ & 0.36 & & \\
\hline Tertiary education & & & $\begin{array}{l}0.95 \\
(0.35,1.82)\end{array}$ & 0.36 & & \\
\hline \multicolumn{7}{|l|}{ District-level } \\
\hline $\begin{array}{l}\text { Doctors, no. of } \\
\text { doctors } / 1,000 \\
\text { inhabitants }\end{array}$ & $\begin{array}{l}2.1 \\
(0.8,12.3)\end{array}$ & 2.7 & $\begin{array}{l}2.5 \\
(1.0,12.3)\end{array}$ & 2.6 & $\begin{array}{l}2.2 \\
(1.0,13.9)\end{array}$ & 2.3 \\
\hline $\begin{array}{l}\text { PM10 concentration, } \\
\mu g / m^{3}\end{array}$ & $\begin{array}{l}45.5 \\
(42.0,48.5)\end{array}$ & 2.5 & $\begin{array}{l}47.0 \\
(42.0,52.0)\end{array}$ & 3.0 & $\begin{array}{l}42.5 \\
(36.0,48.5)\end{array}$ & 3.8 \\
\hline $\begin{array}{l}\text { Park area, } \\
\mathrm{m}^{2} \text { per se }\end{array}$ & $\begin{array}{l}11.0 \\
(3.4,69.5)\end{array}$ & 15.7 & $\begin{array}{l}11.2 \\
(3.4,71.0)\end{array}$ & 16 & $\begin{array}{l}11.5 \\
(3.5,70.7)\end{array}$ & 15.8 \\
\hline $\begin{array}{l}\text { Total amount of local } \\
\text { tax, } 1 \text { million KRW }\end{array}$ & $\begin{array}{l}343204.0 \\
(175219.5, \\
2064262.5)\end{array}$ & 386485 & $\begin{array}{l}417424.0 \\
(211867.0, \\
2862131.5)\end{array}$ & 403339.5 & $\begin{array}{l}477003.5 \\
(229249.0, \\
3014322.0)\end{array}$ & 490568.5 \\
\hline
\end{tabular}

Notes. KRW = Korean Won; PM = Particulate matter. 
Table 2. Housing price elasticity of all-cause mortality: Results of a pooled OLS regression analysis.

\begin{tabular}{|c|c|c|c|c|c|c|c|c|}
\hline \multirow[b]{2}{*}{ Variable } & \multicolumn{2}{|l|}{ Model 1} & \multicolumn{2}{|l|}{ Model 2} & \multicolumn{2}{|l|}{ Model 3} & \multicolumn{2}{|l|}{ Model 4} \\
\hline & $\begin{array}{l}\text { Coefficient } \\
(95 \% \mathrm{CI})\end{array}$ & P-value & $\begin{array}{l}\text { Coefficient } \\
(95 \% \mathrm{CI})\end{array}$ & P-value & $\begin{array}{l}\text { Coefficient } \\
(95 \% \mathrm{CI})\end{array}$ & P-value & $\begin{array}{l}\text { Coefficient } \\
(95 \% \mathrm{CI})\end{array}$ & P-value \\
\hline Intercept & $\begin{array}{l}1.17 \\
(1.07,1.28)\end{array}$ & $<0.001$ & $\begin{array}{l}1.30 \\
(1.12,1.48)\end{array}$ & $<0.001$ & $\begin{array}{l}0.83 \\
(0.34,1.32)\end{array}$ & $<0.001$ & $\begin{array}{l}-0.06 \\
(-0.57,0.44)\end{array}$ & 0.803 \\
\hline \multicolumn{9}{|l|}{ Neighborhood-level } \\
\hline $\ln ($ Housing price $)$ & $\begin{array}{l}-0.20 \\
(-0.22,-0.18)\end{array}$ & $<0.001$ & $\begin{array}{l}-0.15 \\
(-0.17,-0.13)\end{array}$ & $<0.001$ & $\begin{array}{l}-0.11 \\
(-0.13,-0.08)\end{array}$ & $<0.001$ & $\begin{array}{l}-0.05 \\
(-0.08,-0.03)\end{array}$ & $<0.001$ \\
\hline $\ln$ (Poverty) & & & $\begin{array}{l}0.07 \\
(0.06,0.07)\end{array}$ & $<0.001$ & $\begin{array}{l}0.07 \\
(0.06,0.08)\end{array}$ & $<0.001$ & $\begin{array}{l}0.02 \\
(0.01,0.04)\end{array}$ & 0.002 \\
\hline $\ln$ (Population density) & & & $\begin{array}{l}-0.03 \\
(-0.04,-0.01)\end{array}$ & $<0.001$ & $\begin{array}{l}-0.04 \\
(-0.05,-0.02)\end{array}$ & $<0.001$ & $\begin{array}{l}-0.04 \\
(-0.05,-0.03)\end{array}$ & $<0.001$ \\
\hline $\ln$ (Business workers) & & & $\begin{array}{l}0.01 \\
(0.00,0.02)\end{array}$ & 0.057 & $\begin{array}{l}0.02 \\
(0.01,0.03)\end{array}$ & $<0.001$ & $\begin{array}{l}0.02 \\
(0.01,0.03)\end{array}$ & $<0.001$ \\
\hline $\ln$ (Subway stations) & & & $\begin{array}{l}0.01 \\
(0.00,0.02)\end{array}$ & 0.162 & $\begin{array}{l}0.01 \\
(-0.01,0.02)\end{array}$ & 0.280 & $\begin{array}{l}0.00 \\
(-0.01,0.01)\end{array}$ & 0.855 \\
\hline $\ln$ (Primary education) & & & & & & & $\begin{array}{l}0.10 \\
(0.06,0.14)\end{array}$ & $<0.001$ \\
\hline $\ln$ (Tertiary education) & & & & & & & $\begin{array}{l}-0.15 \\
(-0.20,-0.10)\end{array}$ & $<0.001$ \\
\hline \multicolumn{9}{|l|}{ District-level } \\
\hline $\ln$ (Doctors) & & & & & $\begin{array}{l}0.03 \\
(0.01,0.05)\end{array}$ & $<0.001$ & $\begin{array}{l}0.02 \\
(0.01,0.04)\end{array}$ & 0.003 \\
\hline $\ln (\mathrm{PM} 10$ concentration $)$ & & & & & $\begin{array}{l}0.32 \\
(0.21,0.43)\end{array}$ & $<0.001$ & $\begin{array}{l}0.33 \\
(0.22,0.44)\end{array}$ & $<0.001$ \\
\hline $\ln ($ Park area $)$ & & & & & $\begin{array}{l}-0.02 \\
(-0.03,-0.01)\end{array}$ & 0.001 & $\begin{array}{l}-0.01 \\
(-0.02,0.01)\end{array}$ & 0.276 \\
\hline $\ln$ (Local tax) & & & & & $\begin{array}{l}-0.07 \\
(-0.09,-0.05)\end{array}$ & $<0.001$ & $\begin{array}{l}-0.04 \\
(-0.06,-0.02)\end{array}$ & $<0.001$ \\
\hline R-squared & 0.283 & & 0.381 & & 0.419 & & 0.463 & \\
\hline
\end{tabular}

Notes. Model 1 includes the intercept and housing prices in the model. In Model 2, we added the neighborhood-level variables (poverty rate, population density, business workers density, the number of nearby subway stations) to Model 1. In Model 3, we further added the district-level variables (the number of physicians per 1,000 population, PM10 annual concentration, park area per person, local tax) to Model 2. In Model 4, the educational composition was added to Model 3.

$\mathrm{PM}=$ Particulate matter. 
Table 3. Housing price elasticity of all-cause mortality: Results of a spatial panel analysis.

\begin{tabular}{|c|c|c|c|c|}
\hline \multirow{2}{*}{ Variable } & \multicolumn{2}{|l|}{ Model 5} & \multicolumn{2}{|l|}{ Model 6} \\
\hline & $\begin{array}{l}\text { Coefficient } \\
(95 \% \mathrm{CI})\end{array}$ & P-value & $\begin{array}{l}\text { Coefficient } \\
(95 \% \text { CI })\end{array}$ & P-value \\
\hline \multicolumn{5}{|l|}{ Neighborhood-level } \\
\hline $\ln$ (Housing price) & $\begin{array}{l}-0.05 \\
(-0.07,-0.02)\end{array}$ & $<.001$ & $\begin{array}{l}-0.04 \\
(-0.07,-0.02)\end{array}$ & 0.001 \\
\hline $\ln$ (Poverty) & $\begin{array}{l}0.09 \\
(0.08,0.10)\end{array}$ & $<.001$ & $\begin{array}{l}0.09 \\
(0.08,0.10)\end{array}$ & $<.001$ \\
\hline $\ln$ (Population density) & $\begin{array}{l}-0.05 \\
(-0.06,-0.03)\end{array}$ & $<.001$ & $\begin{array}{l}-0.05 \\
(-0.06,-0.04)\end{array}$ & $<.001$ \\
\hline ln(Business workers) & $\begin{array}{l}0.02 \\
(0.00,0.03)\end{array}$ & 0.005 & $\begin{array}{l}0.02 \\
(0.01,0.03)\end{array}$ & 0.001 \\
\hline $\ln$ (Subway stations) & $\begin{array}{l}-0.02 \\
(-0.04,0.00)\end{array}$ & 0.013 & $\begin{array}{l}-0.03 \\
(-0.04,-0.01)\end{array}$ & 0.005 \\
\hline $\mathrm{W} x \ln$ (Housing price) & $\begin{array}{l}-0.05 \\
(-0.09,-0.01)\end{array}$ & 0.012 & $\begin{array}{l}-0.04 \\
(-0.08,0.00)\end{array}$ & 0.074 \\
\hline W x $\ln$ (Poverty) & $\begin{array}{l}0.02 \\
(0.00,0.04)\end{array}$ & $<.001$ & $\begin{array}{l}0.02 \\
(0.00,0.04)\end{array}$ & 0.036 \\
\hline $\mathrm{W} x \ln$ (Population density) & $\begin{array}{l}0.06 \\
(0.04,0.09)\end{array}$ & 0.120 & $\begin{array}{l}0.05 \\
(0.03,0.08)\end{array}$ & $<.001$ \\
\hline $\mathrm{W} \times \ln$ (Business workers) & $\begin{array}{l}-0.01 \\
(-0.03,0.01)\end{array}$ & 0.505 & $\begin{array}{l}0.00 \\
(-0.02,0.02)\end{array}$ & 0.890 \\
\hline W x $\ln$ (Subway stations) & $\begin{array}{l}0.04 \\
(0.02,0.07)\end{array}$ & 0.002 & $\begin{array}{l}0.04 \\
(0.01,0.07)\end{array}$ & 0.005 \\
\hline \multicolumn{5}{|l|}{ District-level } \\
\hline Doctors & & & $\begin{array}{l}0.01 \\
(-0.01,0.03)\end{array}$ & 0.286 \\
\hline PM10 concentration & & & $\begin{array}{l}-0.04 \\
(-0.18,0.10)\end{array}$ & 0.544 \\
\hline Park area & & & $\begin{array}{l}-0.02 \\
(-0.03,0.00)\end{array}$ & 0.006 \\
\hline Local tax & & & $\begin{array}{l}-0.03 \\
(-0.05,-0.01)\end{array}$ & 0.007 \\
\hline Pseudo R-squared & 0.676 & & 0.679 & \\
\hline
\end{tabular}

Notes. We adjusted the neighborhood-level variables (poverty rate, population density, business workers density, and the number of nearby subway stations) and the mean values of adjacent neighborhoods in Model 5 . We further adjusted the district-level variables (the number of physicians per 1,000 population, PM10 annual concentration, park area per person, and local tax) in Model 6.

$\mathrm{PM}=$ Particulate matter; $\mathrm{W}=$ Spatial weight matrix . 


\section{Figures}

(A)

2013-2014

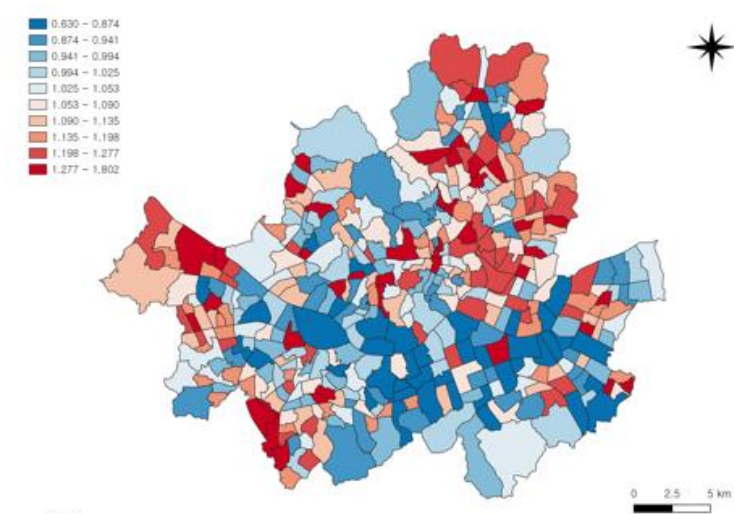

(B)

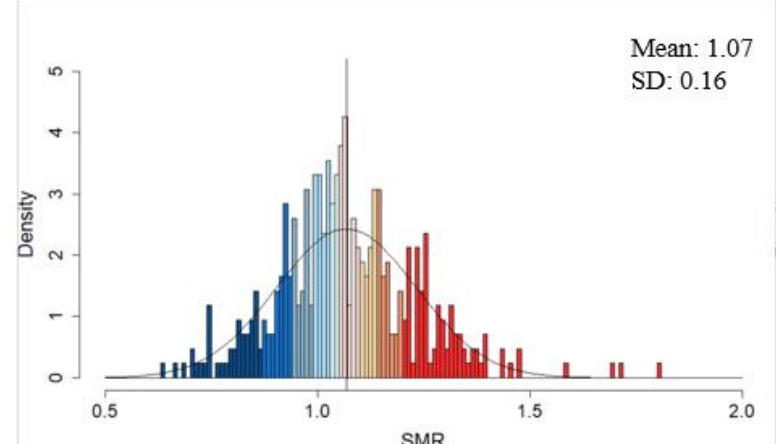

SMR
2015-2016


Figure 1. Mapped distribution (A) and histogram (B) of SMR deciles in Seoul during the study period.

Notes. The solid black line in the lower panel indicates the normal distribution using the mean and SD of SMR.

$\mathrm{SD}=$ Standard deviation; SMR $=$ Standardized mortality ratio. 
(A)
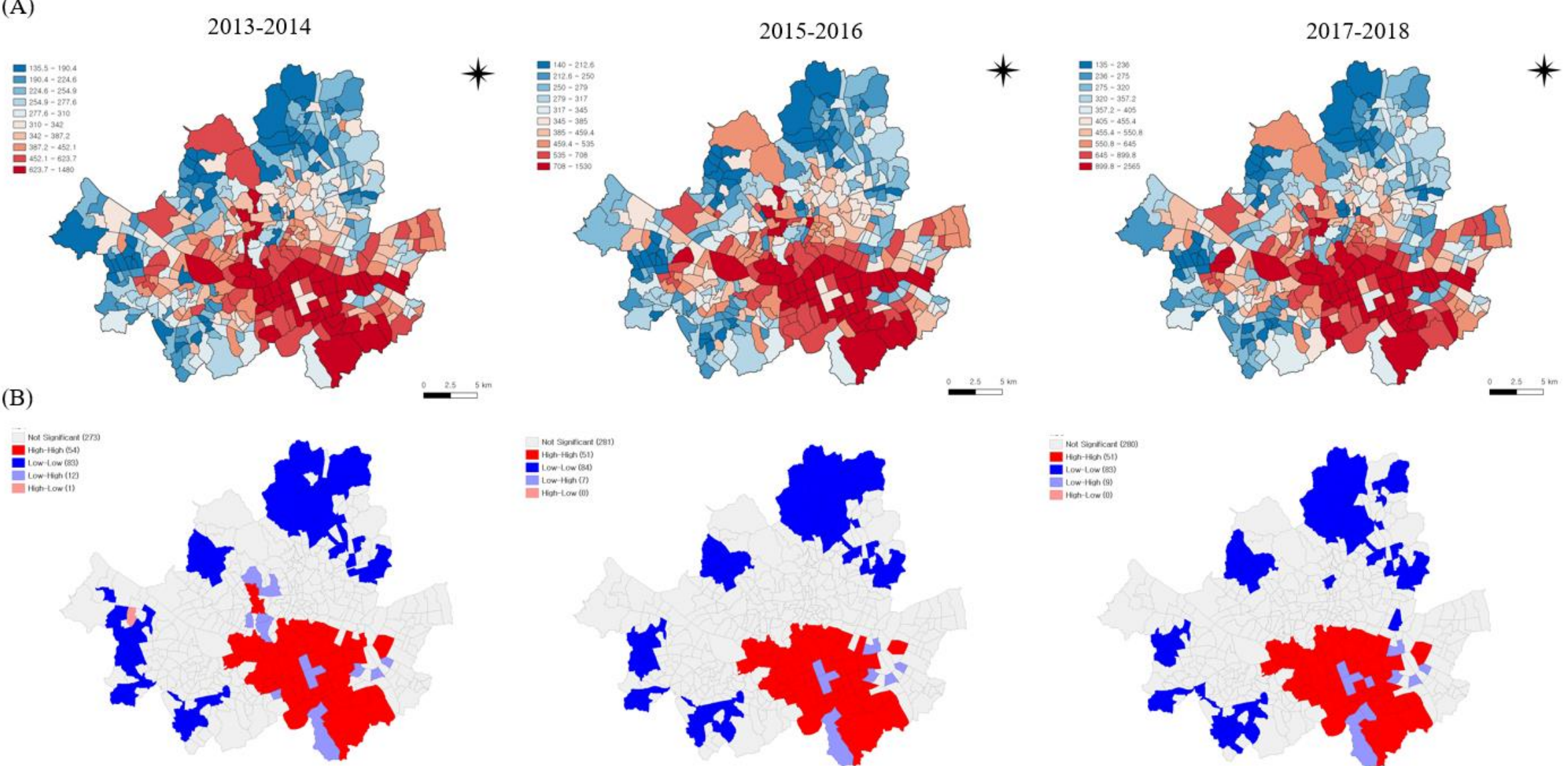

Moran's I $=0.515$

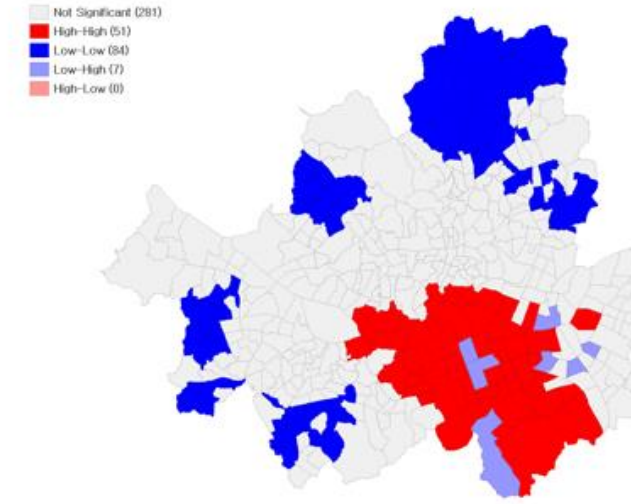

Moran's I $=0.552$

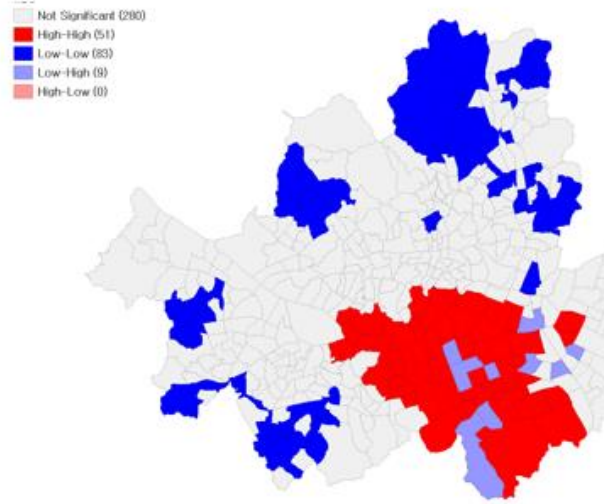

Moran's I $=0.541$

Figure 2. Mapped distribution (A) and spatial patterning (B) of neighborhood-level housing prices in Seoul by study period. Notes. Housing prices in 1 million KRW. 


\section{Figures}

(A)

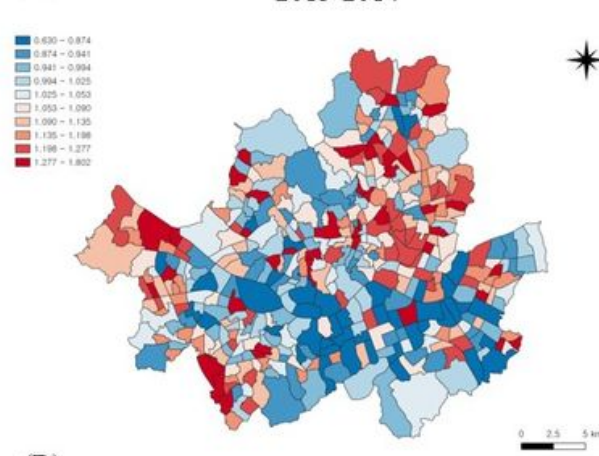

(B)

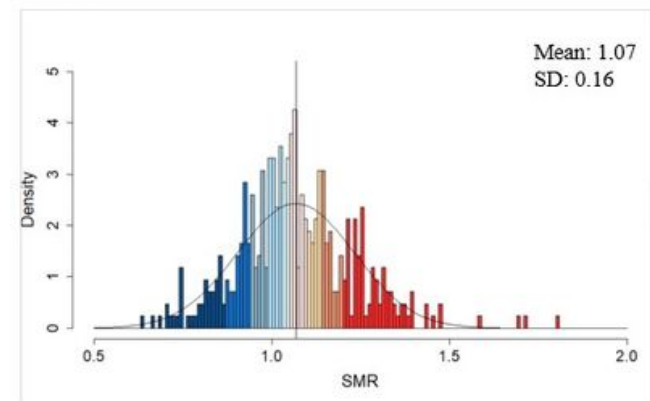

2013-2014

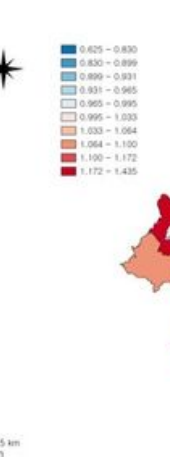

2015-2016

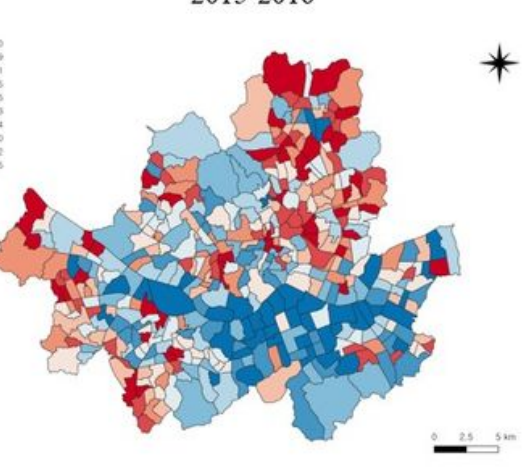

2017-2018
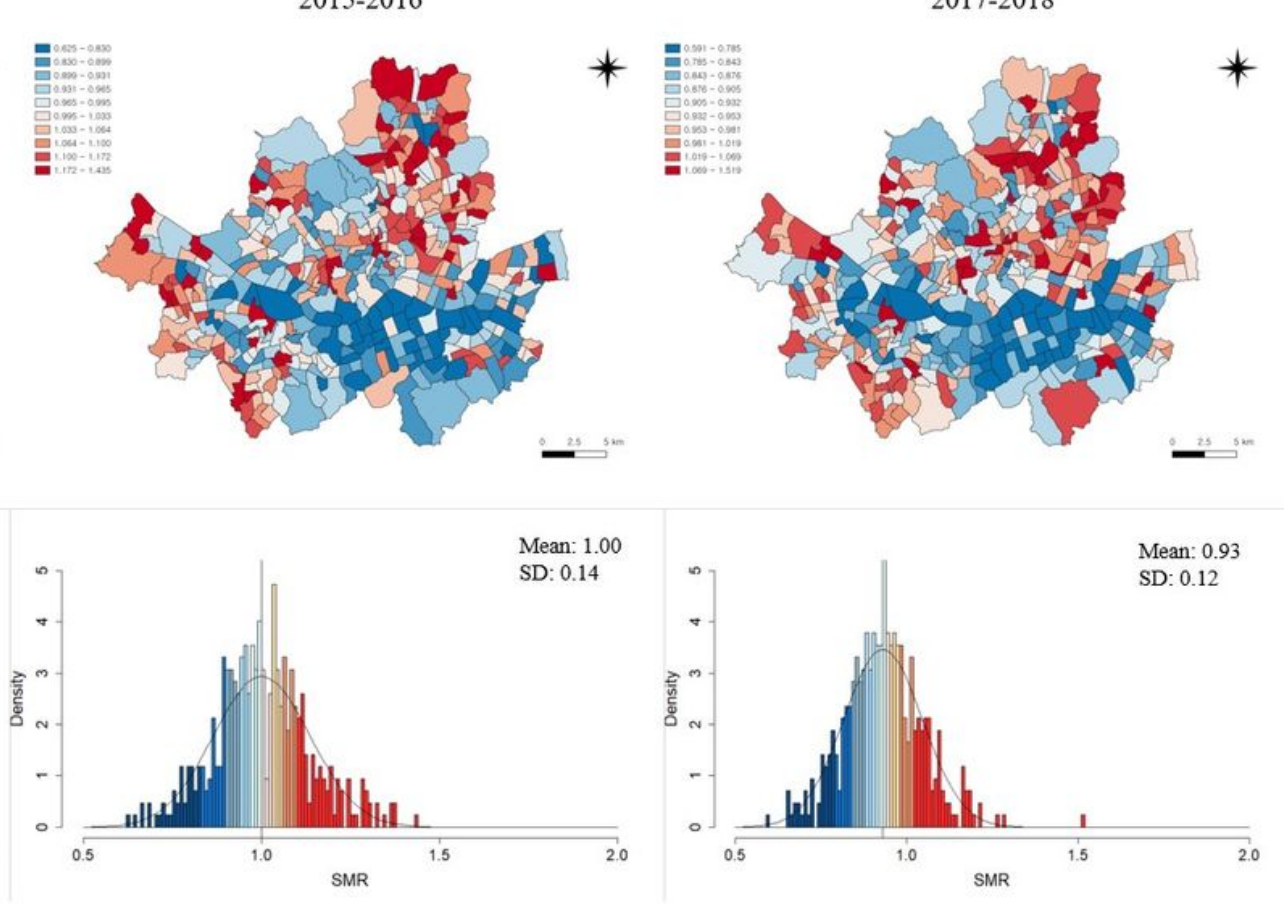

\section{Figure 1}

Mapped distribution (A) and histogram (B) of SMR deciles in Seoul during the study period. Notes. The solid black line in the lower panel indicates the normal distribution using the mean and SD of SMR. SD = Standard deviation; SMR = Standardized mortality ratio. Note: The designations employed and the presentation of the material on this map do not imply the expression of any opinion whatsoever on the part of Research Square concerning the legal status of any country, territory, city or area or of its authorities, or concerning the delimitation of its frontiers or boundaries. This map has been provided by the authors. 
(A)

2013-2014

2015-2016
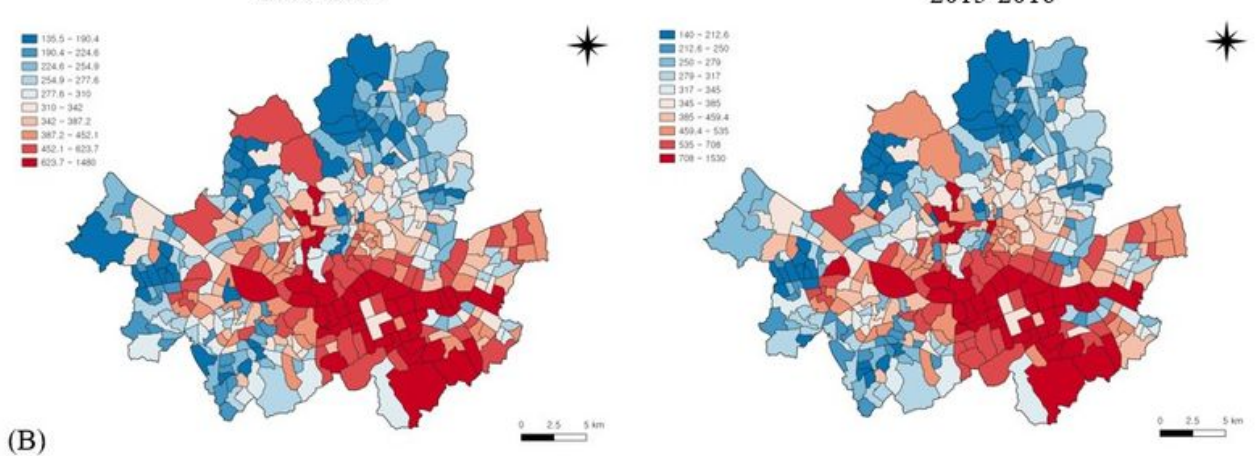

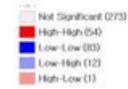

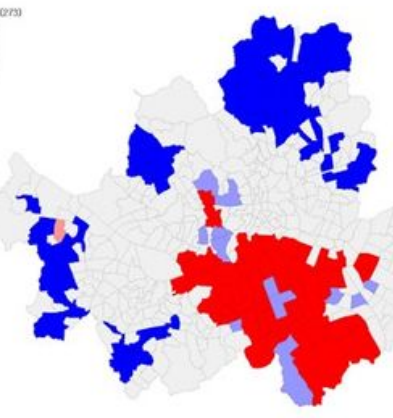

Moran's I $=0.515$

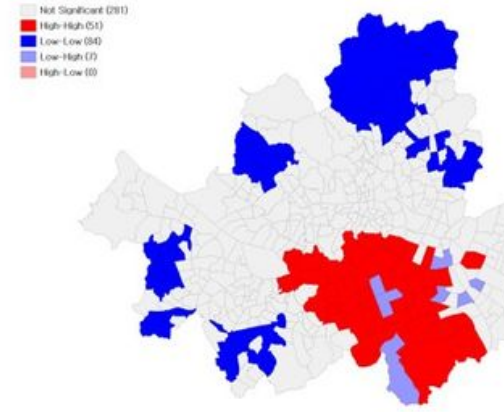

Moran's I $=0.552$
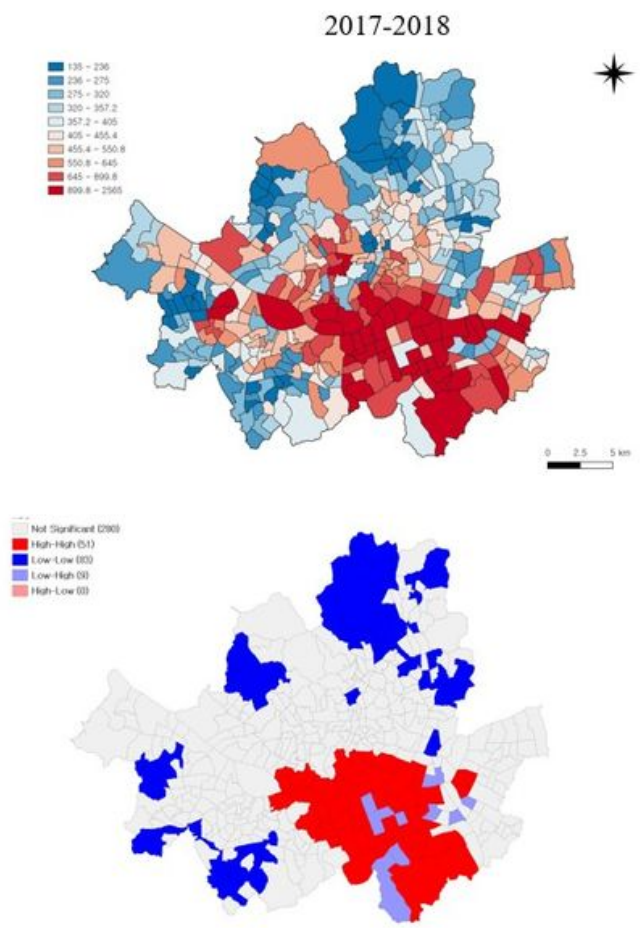

Moran's I $=0.541$

\section{Figure 2}

Mapped distribution (A) and spatial patterning (B) of neighborhood-level housing prices in Seoul by study period. Notes. Housing prices in 1 million KRW. Note: The designations employed and the presentation of the material on this map do not imply the expression of any opinion whatsoever on the part of Research Square concerning the legal status of any country, territory, city or area or of its authorities, or concerning the delimitation of its frontiers or boundaries. This map has been provided by the authors.

\section{Supplementary Files}

This is a list of supplementary files associated with this preprint. Click to download.

- SupplementaryMaterials1220.docx 